\title{
Control over the geotechnical processes at the goldfields of Eastern Siberia
}

\author{
Elena L. Sosnovskaia ${ }^{1}$, Arkadii N. Avdeev ${ }^{1 *}$ \\ ${ }^{1}$ Institute of Mining UB RAS, Ekaterinburg, Russia \\ *e-mail: avdeev0706@mail.ru
}

\begin{abstract}
Introduction. There are more than thousand lode mineral deposits of gold, rare metals, polymetals, and uranium in Eastern Siberia. Only 10\% of them are in operation. Geotechnical conditions of the fields are poorly studied, therefore geotechnological parameters are not explored at a sensibly reliable level. The authors have conducted multi-year research of geotechnical processes at goldfields of Eastern Siberia.

Methodology. During geotechnical processes investigation at goldfields the authors have created the methods and techniques calculating the parameters of stable pillars and chamber exposures, selecting rock pressure control procedures based on the complex analysis of mining and geological factors: physical and mechanical properties of rock and ore, tectonic faulting, cryologic state of rock in a massif, high natural gravitational and tectonic stresses of rock mass, technogenic stresses in structural elements of underground geotechnologies.

Results. For practical use of research results, methodological and normative documents have been developed for a range of mines, including Darasun, Kholbinsky, Irokindinsky, Novo-Shirokinsky, Maiskoe, Konevinsky, Mnogovershinnoye, Birkachan, Kedrovskoe, etc. The documents have undergone expert exanimation of industrial safety and have been approved by RF Rostekhnadzor for practical use at gold mines.
\end{abstract}

Key words: gold lodes; geotechnics; rock pressure control; pillars; chamber roof and walls exposures; physical and mechanical properties of rocks; natural and technogenic stresses.

Introduction. In Eastern Siberia there are more than thousand lode mineral deposits of gold, rare metals, polymetals, and uranium. Only $10 \%$ of them are currently in operation. $50 \%$ of deposits are at the design and construction stage and are planned to be developed in the nearest decades. Deposits are developed with labor intense and high-cost mining systems making metal losses up to $20 \%$ and more as well as increased impoverishment up to $30 \%$ and more. Harmful manifestations of geotechnical processes of displacement and rock pressure in static and dynamic forms are observed. Mine operation is complicated by the presence of significant permafrost up to $200 \mathrm{~m}$ and more. Geotechnical conditions of deposits are generally not explored or poorly explored. For that reason geotechnological parameters are not substantiated at a sensibly reliable level [1-9].

Since 2000 the authors have been carrying out multi-year research of geotechnical processes at lode gold deposits situated in Eastern Siberia. During this time certain methods and techniques of stable pillars and chamber exposure determination parameters have been developed as well as rock pressure control procedures with the account of physical and mechanical properties of rock and ore, tectonic faulting, cryologic state of rock in a massif, high natural gravitational and tectonic rock stresses and technogenic stresses in structural elements of development systems. 
Basic results. Research results for the conditions of lore gold deposits are as follows [10-11].

The classification of rock mass conditions has been worked out according to its stability level in various cryogenic conditions [11]. The classification makes it possible to determine the category of rock mass stability based on the revealed basic mining and geological factors influencing the stability of structural elements of development systems during the extraction of lodes of low and medium thickness in the condition of cryolithic zone $[5,11,12]$. It has been stated that the following geological and engineering-geological conditions directly influence the stability of the roof and walls of stopes during reserves depletion: the inclination angle of a lode and the shape of stoping face roof relief; the presence of the foliation zones and their characteristic; the intensity of relatively large-scale block tectonics; orientation of fissures towards the mine goaf and the degree of their opening, temperature mode and water (ice) phase in the marginal massif.

Qualitative and quantitative characteristics of rock mass source stresses field have been substantiated. Discrete character of rock pressure distribution in local rock has been determined, which creates essentially different geotechnical conditions of reserves extraction. The sections of both medium and high pressure have been discovered in the rock massifs of the deposits.

For the conditions of the medium pressure sections, natural stresses have been determined by in-situ measurements of stresses at 16 lode gold deposits. The algorithms have been developed to calculate stresses in medium pressure zones: in thawed rocks, vertical stresses $\sigma_{v}$ are $-\gamma H$; horizontal longitudinal, along the strike, $\sigma_{1}=-0,95 \gamma H$; horizontal crosscut, across the strike, $\sigma_{c r}=-1,6 \gamma H$, where $\gamma$ - rock and ore density, $\mathrm{MN} / \mathrm{m}^{3}$; $H$ - the depth of mining, $\mathrm{m}$. In cryolithic zone (permafrost) stresses are $\sigma_{v}=\sigma_{1}=\sigma_{c r}=-\gamma H$.

In high pressure zones the values of natural stresses are determined based on inversed geotechnical problems solution according to the data from actual rock pressure manifestations at deep horizons of mines in operation. Stresses are calculated as follows: $\sigma_{v}=-\gamma H ; \sigma_{1}=\sigma_{c r}=-2,5 \gamma H$.

According to research results, the matrix of rock massifs natural stresses at lode gold deposits [4] has been built. The matrix of natural stresses is the basis for the substantiation of rock pressure control methods, geotechnological parameters determination, and mine workings and pillars bump hazard assessment.

For the conditions of low- and medium-thickness ore bodies mining using the systems with open faces, the technique of stable pillars and chamber exposure determination by L. I. Sosnovsky has been improved [2, 11, 13].

The main provisions of the technique are as follows.

The condition of operation blocks stability is approximated by the following expressions:

$$
\begin{gathered}
\sigma_{p}=\left[\left(K_{y p} \sigma_{v}+K_{x p} \sigma_{h}\right)-\sigma_{h}\right] K_{v o l}+\sigma_{h} \leq \sigma_{\lim } K_{C} ; \\
\sigma_{w}=\left(K_{y w} \sigma_{v}+K_{x w} \sigma_{h}\right) K_{v o l} \leq \sigma_{\lim } ; \\
l_{p} \geq \frac{l_{c h} H_{f} \sigma_{h} K_{1} K_{2} K_{v o l}}{\left[\sigma_{\lim }-\sigma_{h}\left(1-K_{v o l}\right)\right] A}-\frac{\left(l_{c h}-l_{u p}\right) h}{A}+l_{u p},
\end{gathered}
$$

where $\sigma_{p}$ - stresses in the floor (arch) pillar, MPa; $K_{y p}, K_{x p}$ - concentration ratios of technogenic stresses caused by vertical and horizontal single loads in floor (arch) pillar; $K_{y w}, K_{x w}$ - concentration ratio of technogenic stresses caused by vertical and horizontal single loads in chamber walls; $\sigma_{v}, \sigma_{h}-$ stresses in undisturbed massif (source), acting 
vertically and horizontally correspondingly, $\mathrm{MPa} ; K_{v o l}$ - the coefficient of transition from two-dimensional to three-dimensional geotechnical problem; $\sigma_{\text {lim }}-$ rock compressive (tensile) strength in a massif, $\mathrm{MPa} ; K_{C}$ - coefficient taking into account the geometry of a pillar (Cern coefficient); $\sigma_{w}$-stresses in a wall (edges) of a chamber, MPa; $K_{v w}, K_{h w}$ - concentration ratios of stresses from the action of vertical and horizontal single loads in the wall (edges) of a chamber; $l_{c h}$ - chamber length, $\mathrm{m} ; H_{f}$ - average length of a floor, $\mathrm{m} ; K_{1}$ - the coefficient taking into account the influence of vertical stresses; $K_{2}$ - the coefficient characterizing the influence of irregularity in the distribution of vertical stresses under various number of abandoned levels; $l_{u p}$ - the width of upraise, $\mathrm{m}$; $h$ - the height of an intervenning pillar, $\mathrm{m} ; A$ - the total height of an arch pillar with the account of cut-through, $\mathrm{m}$.

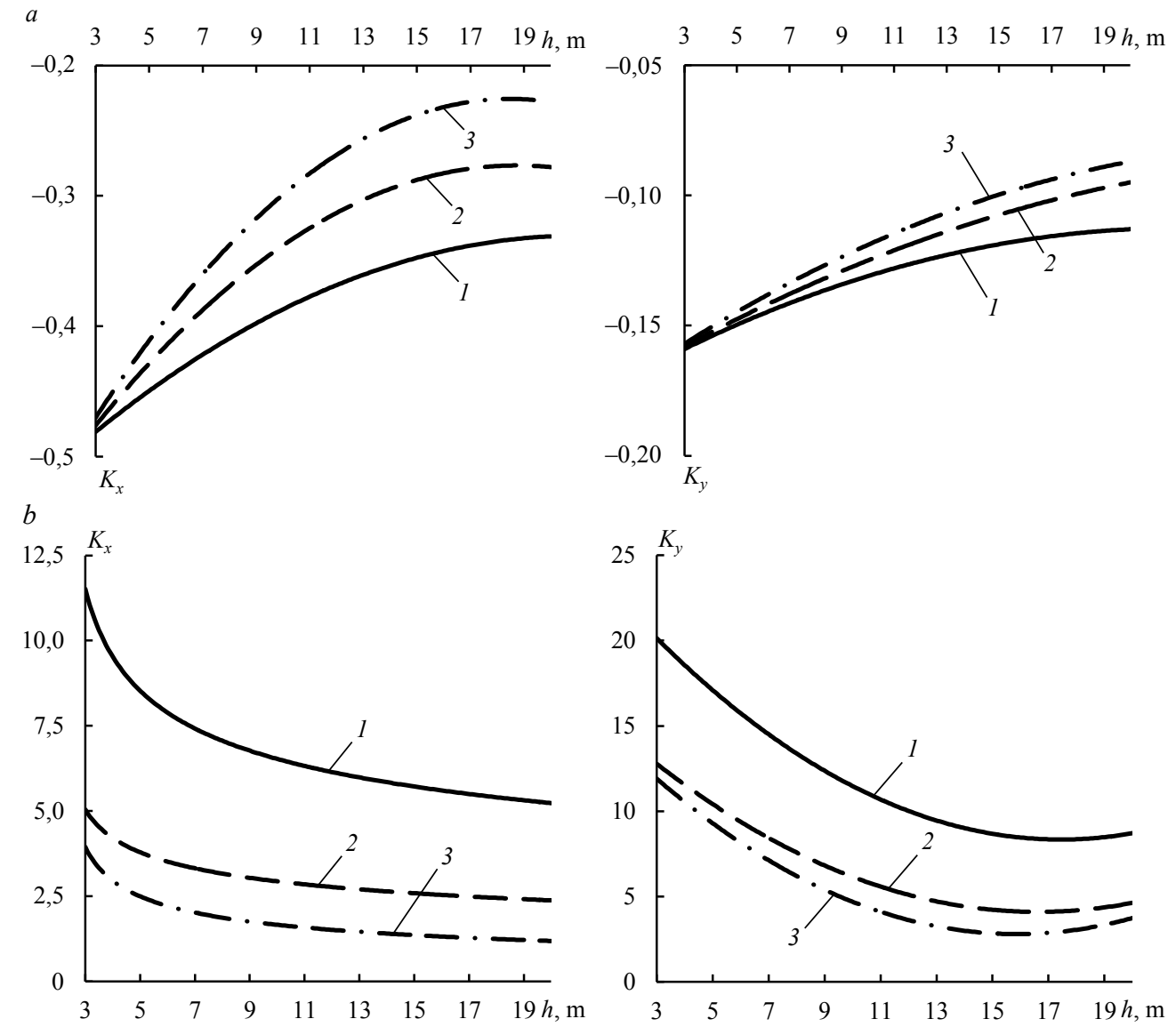

Fig. 1. Stress concentration ratios $K_{x}$ и $K_{y}$ in stope roof $-a$ and in floor pillar during inclined lodes mining with the working thickness of $1-3 \mathrm{~m}-b$ :

$1,2,3$ - working thicknesses of an ore body, $\mathrm{m} ; h$ - the height of the floor pillar, $\mathrm{m}$

Рис. 1. Коэффициенты концентрации напряжений $K_{x}$ и $K_{y}$ в кровле очистной камеры - $a$ и в междуэтажном целике при отработке наклонных жил выемочной мощностью $1-3 \mathrm{~m}-b$ :

1, 2, 3 - выемочные мощности рудного тела, м; $h$ - толщина междуэтажного целика, м

Stresses concentration ratios are proposed to be determined based on the nomograms developed with finite element method (fig. 1,2). Concentration ratios of technogenic stresses in the walls and roof of chambers and floor pillars are established depending on the angel of incidence of ore lode and its working thickness [11, 13, 14].

Stresses in undisturbed massif are set up according to the natural stress matrix of lode gold deposits depending on the depth of mining [4]. The coefficient of transition 
from the two-dimensional to the three-dimensional geotechnical problem is advisable to determine according to the methods of A. V. Zubkov [3].

Compressive strength and tensile strength of rock in a massif is determined from the following expressions

$$
\sigma_{\lim }=\frac{\sigma^{s} K_{s t r} K_{C}}{K_{m l}} ; \quad K_{s t r}=\frac{1}{0.53\left(l / l_{b l}+1.75\right)}+0.315+\Delta,
$$

where $\sigma^{s}$ - compressive strength or tensile strength of rock in a sample, MPa; $K_{s t r}$ - the coefficient of structural weakening; $K_{m l}$ - the coefficient of long-term strength,
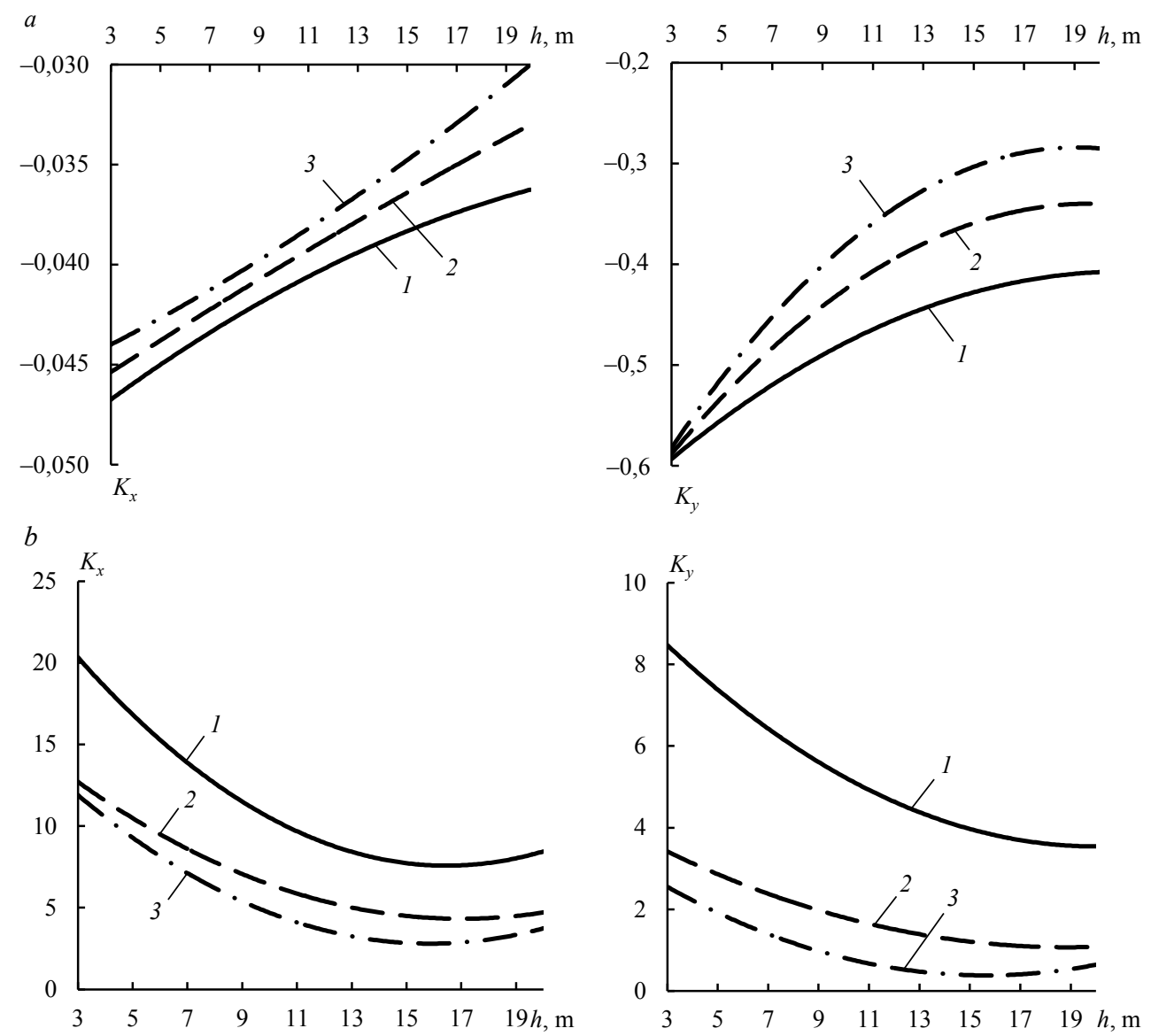

Fig. 2. Stress concentration ratios $K_{x}$ и $K_{y}$ in the stope wall $-a$ and in the floor pillar during inclined lodes mining with the working thickness of $1-3 \mathrm{~m}-b$ :

$1,2,3$ - working thicknesses of an ore body, $\mathrm{m} ; h$ - the height of the floor pillar, $\mathrm{m}$

Рис. 2. Коэффициенты концентрации напряжений $K_{x}$ и $K_{y}$ в стенке очистной камеры $-a$ и в междуэтажном целике при отработке крутопадающих жил выемочной мощностью $1-3 \mathrm{~m}-b$ : $1,2,3$ - выемочные мощности рудного тела, м; $h$ - толщина междуэтажного целика, м

based on the life of mine workings and pillars; $l$ - the linear size of the massif section which is assessed for strength, $\mathrm{m} ; l_{b l}$ - the linear size of a structural block, $\mathrm{m}$; $\Delta$ - the correction which takes into account the influence of subzero temperatures.

Correction $\Delta$ elaborates the algorithm of VNIMI; the suggested value of the correction is 0.4 for the conditions of permafrost, 0.2 for the zones of permafrost 
transition into thawed rock, and 0 for the thawed rock $[5,11,12,15]$. The use of correction $\Delta$ leads to the fact that the design factor of structural weakening increases and makes up approximately 1 in the conditions of permafrost, i. e. jointing does not exert significant influence in permafrost. In the process of temperature rise the cohesion of the permafrost rocks reduces, and the well-known methods of VNIMI can be used for the thawed rock.

The coefficient of long-term strength can be applied according to the methods of the Institute of Rock Physics and Mechanics $[2,16]$ in compliance with the design spell of service of the pillars $t$, required to mine the blocks and eliminate the voids, equal to 1.4-1.5. The Cern coefficient for the floor pillar is determined from the well-known formula [2]:

$$
K_{C}=\sqrt{\frac{h_{p}}{m}},
$$

where $h_{p}$ - the height of the pillar, $\mathrm{m}$; $m$ - working thickness of the lode, $\mathrm{m}$.

When assessing the stability of walls of the stope, the coefficient of form of formula (1) is not taken into account.

Table 1. The parameters of pillars for the steeply pitching lodes of low and middle thickness mining with the systems with ore shrinkage

Таблица 1. Параметры целиков при отработке крутопадающих рудных тел малой и средней мощности системами с мелкошпуровой отбойкой руды

\begin{tabular}{|c|c|c|c|c|c|c|c|}
\hline \multirow[b]{2}{*}{$\begin{array}{l}\text { The depth } \\
\text { of mining, } \\
\mathrm{m}\end{array}$} & \multirow{2}{*}{$\begin{array}{l}\text { The } \\
\text { thick- } \\
\text { ness of } \\
\text { an ore } \\
\text { body, m }\end{array}$} & \multicolumn{3}{|c|}{ One level mining } & \multicolumn{3}{|c|}{ Two levels mining } \\
\hline & & $\begin{array}{c}\text { Arch } \\
\text { pillar, } \mathrm{m}\end{array}$ & $\begin{array}{l}\text { Intervenning } \\
\text { pillar (inteme- } \\
\text { diate), m }\end{array}$ & $\begin{array}{l}\text { Activities ensur- } \\
\text { ing the stability } \\
\text { of a block }\end{array}$ & $\begin{array}{c}\text { Arch } \\
\text { pillar, } \mathrm{m}\end{array}$ & $\begin{array}{l}\text { Intervenning } \\
\text { pillar (inteme- } \\
\text { diate), m }\end{array}$ & $\begin{array}{l}\text { Activities ensur- } \\
\text { ing the stability } \\
\text { of a block }\end{array}$ \\
\hline \multirow[t]{3}{*}{ Up to 200} & 1 & 2 & 7 & - & 3 & 7 & - \\
\hline & 2 & 2 & 7 & - & 3 & 8 & - \\
\hline & 3 & 3 & 8 & - & 4 & 8 & - \\
\hline \multirow[t]{3}{*}{$200-400$} & 1 & 3 & 8 & Extraction by & 4 & 8 & Extraction by \\
\hline & 2 & 3 & 8 & $\begin{array}{c}\text { the ribbons } \\
10-20 \mathrm{~m}\end{array}$ & 4 & 8 & \\
\hline & 3 & 4 & 8 & length. Cham- & 4 & 8 & length. Cham- \\
\hline \multirow[t]{3}{*}{$400-600$} & 1 & 4 & 8 & $\begin{array}{l}\text { ber walls sup- } \\
\text { porting with }\end{array}$ & 4 & 8 & $\begin{array}{l}\text { ber walls sup- } \\
\text { porting with }\end{array}$ \\
\hline & 2 & 4 & 8 & wood & 4 & 8 & wood \\
\hline & 3 & 4 & 8 & & 4 & 8 & \\
\hline
\end{tabular}

Based on the given methods the parameters of stable pillars are substantiated for the steeply pitching lodes of low and middle thickness under open-stope mining and ore shrinkage (table 1), as well as the parameters of stable pillars under the systems of inclined ore bodies development (table 2) [11, 13].

It has been stated that at the mining depth up to $200 \mathrm{~m}$ the dimensions of stable pillars and chamber exposures can be determined by the proposed methods. The volume of ore in pillars in the case will be about $20 \%$ of the reserves of the block. At the depths of 200-600 $\mathrm{m}$ the dimensions of stable pillars will significantly increase to lead to unreasonably serious ore loss up to $40 \%$ and more. For that reason at the depths of 200-600 m additional activities ensuring the reduction of stresses in structural elements of development systems are necessary; it is also necessary to keep smaller pillars.

The following activities ensuring the stability of stopes have been proposed. 
When mining steeply-pitching narrow lodes, to ensure the stability of arch pillars and the edges of chambers, it is proposed to mine the reserves in the operation block by the ribbons of 10-20 $\mathrm{m}$ width but not by breast. Under these activities, design stresses in arch pillar and chamber wall are smaller than the allowable ones even at great depths, because the major share of stresses is born by the adjoining massif but not by the edges of a pillar.

In the process of simulating stopes walls stress-strain state when mining steeplypitching ore bodies, with the help of the finite element method, the size of the zone of disintegrating layer has been determined, which changes from 3 to $5 \mathrm{~m}$ depending on the thickness of an ore body and the depth of mining. It is proposed to support this zone with anchor and anchor-cable support at sublevels to ensure the stability of the direct roof of the overlying rock.

Table 2. The parameters of pillars under the development systems of steeply pitching lodes of low and middle thickness with an open stope

Таблица 2. Параметры целиков при системах разработки наклонных рудных тел малой и средней мощности с открытым очистным пространством

\begin{tabular}{|c|c|c|c|c|c|c|c|c|c|}
\hline \multirow[b]{2}{*}{$\begin{array}{c}\text { The depth } \\
\text { of mining, } \\
\mathrm{m}\end{array}$} & \multirow[b]{2}{*}{$\begin{array}{c}\text { The thick- } \\
\text { ness of an } \\
\text { ore body, } \\
\text { m }\end{array}$} & \multicolumn{4}{|c|}{ One level mining } & \multicolumn{4}{|c|}{ Two levels mining } \\
\hline & & $\begin{array}{c}\text { Stump } \\
\text { pillar, m }\end{array}$ & $\begin{array}{c}\text { Arch } \\
\text { pillar, m }\end{array}$ & $\begin{array}{c}\text { Inter- } \\
\text { venning } \\
\text { pillar, m }\end{array}$ & $\begin{array}{c}\text { Activities } \\
\text { ensuring the } \\
\text { stability of a } \\
\text { block }\end{array}$ & $\begin{array}{c}\text { Stump } \\
\text { pillar, m }\end{array}$ & $\begin{array}{c}\text { Arch } \\
\text { pillar, m }\end{array}$ & $\begin{array}{c}\text { Inter- } \\
\text { venning } \\
\text { pillar, m }\end{array}$ & $\begin{array}{c}\text { Activities } \\
\text { ensuring the } \\
\text { stability of a } \\
\text { block }\end{array}$ \\
\hline \multirow[t]{3}{*}{ Up to 200} & 1 & 2 & 2 & 6 & \multirow{9}{*}{$\begin{array}{l}\text { Roof sup- } \\
\text { port with } \\
\text { the pit } \\
\text { props or } \\
\text { anchors }\end{array}$} & 2 & 2 & 6 & \multirow{9}{*}{$\begin{array}{l}\text { Roof sup- } \\
\text { port with the } \\
\text { pit props. } \\
\text { Voids elim- } \\
\text { ination by } \\
\text { the con- } \\
\text { trolled rocks } \\
\text { self-collapse }\end{array}$} \\
\hline & 2 & 2 & 2 & 6 & & 2 & 2 & 6 & \\
\hline & 3 & 3 & 3 & 6 & & 3 & 3 & 6 & \\
\hline \multirow[t]{3}{*}{$200-400$} & 1 & 2 & 2 & 6 & & 3 & 3 & 6 & \\
\hline & 2 & 2 & 2 & 6 & & 3 & 3 & 6 & \\
\hline & 3 & 3 & 3 & 6 & & 3 & 4 & 6 & \\
\hline \multirow[t]{3}{*}{$400-600$} & 1 & 3 & 3 & 6 & & 3 & 3 & 6 & \\
\hline & 2 & 3 & 3 & 6 & & 3 & 4 & 6 & \\
\hline & 3 & 4 & 4 & 6 & & 4 & 4 & 6 & \\
\hline
\end{tabular}

At great depths (400-600 $\mathrm{m}$ and deeper) a need arises to take some measures preventing the manifestation of rock pressure in dynamic forms [6]. For the conditions of lode deposits it is proposed to take the complex of special measures: getting the mine workings into the bump hazard state, field development of ore bodies, giving hipped roof shape to the pillars, creating the elements of pliability in pillars $[2,10,11,17]$.

Simulation of the development of inclined lodes of low and medium thickness determined the size of the zone of possible caving in heading and hanging sides of chambers, which is equal to 1-2 $\mathrm{m}$ in order to ensure the stability of operation blocks it is proposed to support the roof with the pit props or anchors.

Upon extraction of inclined lodes reserves at one or two levels, subsurface voids are recommended to be eliminated by controlled rocks self-collapse. It has been stated that the most favourable conditions for controlled self-collapse of roof at lodes are roof surface troughs where it's possible to control the self-collapse process $[5,11,12,15]$. Caved sections of rock support the roof and prevent caving at vast areas and allow avoiding the hazard of technogenic manifestations, such as impulse air wave and overpressure.

Conclusion. Basic recommendations of the research have been applied by design agencies in mining projects development: OAO Irgiredmet at Darasun mine and Karalveem mine, Buryatzoloto at Kholbinsky and Irokindinsky fields, JSC Polymetal 
at Maiskoe and Birkachan fields, Mnogovershinnoye at Mnogovershinnoye mine, OOO Hooshzir Enterprises at Konevinsky mine, OOO Artel Staratelei Zapadnaia at Kedrovskoe field.

For practical use of research results for the conditions of certain mines, methodological and normative documents have been developed, including:

- directions for the determination of structural parameters of development systems;

- directions and manufacturing instructions for support and maintenance of capital, development, face, stoping, and exploration headings;

- directions for structures, natural objects, and mine workings protection from the harmful effect of underground mining;

- directions for secure mining;

- directions for the organization of geotechnical condition complex monitoring.

The documents have been developed for a rande of mines, including Darasun, Kholbinsky, Irokindinsky, Novo-Shirokinsky, Maiskoe, Konevinsky, Mnogovershinnoye, Birkachan, Kedrovskoe, etc.

The documents have undergone expert exanimation of industrial safety at OAO Irgiredmet, ANO Zabaikalskii gornotekhnicheskii tsentr, OOO Sibirskaia proektnaia ekspertnaia kompaniia. The documents have been approved by RF Rostekhnadzor for practical use at gold mines.

\section{REFERENCES}

1. Vlokh N. P. Rock pressure control at underground mines. Moscow: Nedra Publishing; 1994. (In Russ.)

2. Neganov V. P. (ed.) Gold fields development technology. Moscow: Nedra Publishing; 1995. (In Russ.)

3. Zubkov A. V. Geomechanics and Geotechnology. Ekaterinburg: UB RAS Publishing. (In Russ.)

4. Sosnovskaia E. L., Iasychenko V. B. Justification of the matrix of natural stresses of vein deposit rock massifs in Siberia and Far East. Vestnik Irkutskogo gosudarstvennogo tekhnicheskogo universiteta = Proceedings of Irkutsk State Technical University. 2011; 11: 74-78. (In Russ.)

5. Pavlov A. M., Semenov Iu. M., Sosnovskii L. I. Rock pressure control in permafrost massifs under low thickness inclined lodes underground mining at Irokindinskii gold field. In: Geodynamics and Stress state of the Earth's interior: scientific conference proceedings. Novosibirks: IM SB RAS Publishing; 2008. P. 477-481. (In Russ.)

6. Sosnovskaia E. L., Avdeev A. N. The forecast of potential rock bump hazard of steeply pitching lode gold ore deposits. Izvestiya vysshikh uchebnykh zavedenii. Gornyi zhurnal = News of the Higher Institutions. Mining Journal. 2016; 2: 74-85. (In Russ.)

7. Cluff D. L., Kazakidis V. N. Opportunities and constraints of engineering frozen backfill for underground mining applications in permafrost. Proceedings of the 10th Int. Symp. on Cold Regions Development. Alaska, 2013: 175-190.

8. Kight G., Harris M., Gorski B., Udd J. E. Frozen backfill research for canadian mines. Canada: Centre for Mineral and Energy Technology, 1994. $21 \mathrm{p}$.

9. Coil D., Lester E., Higman B. Gold mining methods. Ground Truth Trekking. 2014. 2 p.

10. Sosnovskii L. I., Zubkov A. V. Flowsheets of stoping with pliable pillars at Berezovsky deposit. Vestnik Irkutskogo gosudarstvennogo tekhnicheskogo universiteta = Proceedings of Irkutsk State Technical University. 2007; 1 (1): 92-95. (In Russ.)

11. Sosnovskaia E. L. Rationale for the parameters of underground geotechnology of low thickness inclined lodes development. Vestnik Irkutskogo gosudarstvennogo tekhnicheskogo universiteta = Proceedings of Irkutsk State Technical University. 2015; 5: 60-68. (In Russ.)

12. Pavlov A. M., Semenov Iu. M., Sosnovskii L. I. Evaluation of parameters of stable pillars and room roofs inunderlay lode mining in cryogenic zones in terms of the Irokindinsly gold deposit. Gornyi informatsionno-analiticheskii biulleten (nauchno-tekhnicheskii zhurnal) = Mining Informational and Analytical Bulletin (scientific and technical journal). 2008; 5: 142-147. (In Russ.)

13. Sosnovskaia E. L. Assessment of technogenic stresses in stopes when developing thin steeply dipping gold-ore veins. Vestnik Irkutskogo gosudarstvennogo tekhnicheskogo universiteta = Proceedings of Irkutsk State Technical University. 2014; 12: 82-88. (In Russ.)

14. Reddy J. N. An introduction to nonlinear finite element analysis. Oxford: Oxford University Press, 2004. $488 \mathrm{p}$.

15. Pavlov A. M., Semenov Iu. M. Rock pressure control in sryolitic zone when mining inclined narrow lodes by the example of Irokindinsky field. Gornyi informatsionno-analiticheskii biulleten (nauchno-tekhnicheskii zhurnal) = Mining Informational and Analytical Bulletin (scientific and technical journal). 2007: 11: 30-34. (In Russ.)

16. Ialymov N. G. Rock mass stresses state research at ore deposits of Kyrgyzstan. Prikladnye zadachi mekhaniki gornykh porod = Applied Problems of Rock Mechanics. Moscow: Nauka Publishing; 1977. (In Russ.) 
17. Pavlov A. M. Rationale for the parameters of underground geotechnology of lode gold fields based on the detection and use of geological medium fractal properties. Gornyi informatsionno-analiticheskii biulleten (nauchno-tekhnicheskii zhurnal) = Mining Informational and Analytical Bulletin (scientific and technical journal). 2011; 4: 106-112. (In Russ.)

Received 29 January 2019

\section{Сведения об авторах:}

Elena L. Sosnovskaia - PhD (Geology and Mineralogy), senior researcher of the Laboratory of Geodynamics and Rock Pressure, Institute of Mining UB RAS. E-mail: stress.igd@mail.ru Arkadii N. Avdeev - PhD (Engineering), senior researcher of the Laboratory of Geodynamics and Rock Pressure, Institute of Mining UB RAS. E-mail: avdeev0706@mail.ru

DOI: $10.21440 / 0536-1028-2019-5-21-29$

\section{Управление геомеханическими процессами на золоторудных жильных месторождениях Восточной Сибири}

Сосновская Е. Л. ${ }^{1}$, Авдеев А. Н.1

${ }^{1}$ Институт горного дела УрО РАН, Екатеринбург, Россия.

\section{Peфepam}

Введение. В Восточной Сибири выявлено более тысячи жильных месторождений полезных ископаемых - золота, редких металлов, полиметаллов, урана. В эксплуатачии из них находится только $10 \%$ Геомеханические условия месторождений мало изучены, поэтому обоснования параметров геотехнологий при их освоении на достаточно надежном уровне не производится. В течение двадияати лет авторами работы проводились исследования геомеханических проиессов золоторудных месторождений Восточной Сибири.

Методики. В проиессе исследований геомеханических процессов на золоторудных жильных месторождениях разработаны авторские методы и методики определения параметров устойчивых иеликов и обнажений камер, выбора способов управления горным давлением на основе комплексного анализа горно-геологических факторов: физико-механических свойств горных пород и руд, тектонической нарушенности, криологического состояния горных пород в массиве, высоких природных гравитационно-тектонических напряжений массива горных пород, техногенных напряжений в конструктивных элементах подземных геотехнологий.

Результаты. Для практического использования результатов разработаны методические и нормативныле документы для ряда рудников, в том числе Дарасунского, Холбинского, Ирокиндинского, Ново-Широкинского, Майского, Коневинского, Многовериинного, Биркачанского и других. Документы прошли экспертизу промышленной безопасности; рекомендованы органами Ростехнадзора РФ для практического применения на золотодобывающих предприятиях.

Ключевые слова: золоторудные жиль; геомеханика; управление горным давлением; иелики; обнажения кровли и стенок очистных камер; физико-механические свойства горных пород; природные и техногенные напряжения.

\section{БИБЛИОГРАФИЧЕСКИЙ СПИСОК}

1. Влох Н. П. Управление горным давлением на подземных рудниках. М.: Недра, 1994. 208 с.

2. Технология разработки золоторудных месторождений / под ред. В. П. Неганова. М.: Недра, 1995. $336 \mathrm{c}$.

3. Зубков А. В. Геомеханика и геотехнология. Екатеринбург: УрО РАН, 2001. 335 с.

4. Сосновская Е. Л., Ясыченко В. Б. Обоснование матрицы природных напряжений массива горных пород жильных месторождений Сибири и Дальнего Востока // Вестник ИрГТУ. 2011. № 11. С. 74-78.

5. Павлов А. М., Семенов Ю. М., Сосновский Л. И. Управление горным давлением в многолетнемерзлых массивах при подземной разработке наклонных жил малой мощности Ирокиндинского золоторудного месторождения // Геодинамика и напряженное состояние недр Земли: тр. науч. конф. Новосибирск: ИГД СО РАН, 2008. С. 477-481.

6. Сосновская Е. Л., Авдеев А. Н. Прогноз потенциальной удароопасности крутопадающих жильных золоторудных месторождений // Известия вузов. Горный журнал. 2016. № 2. С. 74-85.

7. Cluff D. L., Kazakidis V. N. Opportunities and constraints of engineering frozen backfill for underground mining applications in permafrost // Proceedings of the 10th Int. Symp. on Cold Regions Development. Alaska, 2013. P. 175-190.

8. Kight G., Harris M., Gorski B., Udd J. E. Frozen backfill research for canadian mines. Canada: Centre for Mineral and Energy Technology, 1994. $21 \mathrm{p}$.

9. Coil D., Lester E., Higman B. Gold mining methods // Ground Truth Trekking. 2014. 2 p.

10. Сосновский Л. И., Зубков А. В. Технологические схемы ведения очистных работ с податливыми целиками на Березовском месторождении // Вестник ИрГТУ. 2007. Том 1. № 1. С. 92-95. 
11. Сосновская Е. Л. Обоснование параметров подземной геотехнологии разработки наклонных жил малой мощности // Вестник ИрГТУ. 2015. № 5. С. 60-68.

12. Павлов А. М., Семенов Ю. М., Сосновский Л. И. Определение параметров устойчивых целиков и обнажений камер при разработке наклонных жил в криогенных зонах в условиях Ирокиндинского золоторудного месторождения // ГИАБ. 2008. № 5. С. 142-147.

13. Сосновская Е. Л. Оценка техногенных напряжений на контуре очистных камер при разработке крутопадающих золоторудных жил малой мощности // Вестник ИрГТУ. 2014. № 12. С. 82-88.

14. Reddy J. N. An introduction to nonlinear finite element analysis. Oxford: Oxford University Press, 2004. $488 \mathrm{p}$.

15. Павлов А. М., Семенов Ю. М. Управление горным давлением в криолитозоне при отработке наклонных маломощных жил на примере Ирокиндинского месторождения // ГИАБ. 2007. № 11. С. 30-34.

16. Ялымов Н. Г. Исследование напряженного состояния массива горных пород на рудных месторождениях Киргизии // Прикладные задачи механики горных пород. М.: Наука, 1977. С. 26-27.

17. Павлов А. М. Обоснование параметров подземной геотехнологии жильных золоторудных месторождений на основе выявления и использования свойств фрактальности геологической среды // ГИАБ. 2011. № 4. С. 106-112.

Поступила в редакцию 29 января 2019 года

\section{Сведения об авторах:}

Сосновская Елена Леонидовна - кандидат геолого-минералогических наук, старший научный сотрудник лаборатории геодинамики и горного давления Института горного дела УрО РАН. E-mail: stress.igd@mail.ru

Авдеев Аркадий Николаевич - кандидат технических наук, старший научный сотрудник лаборатории геодинамики и горного давления Института горного дела УрО РАН. E-mail: avdeev0706@mail.ru

Для цитирования: Сосновская Е. Л., Авдеев А. Н. Управление геомеханическими процессами на золоторудных жильных месторождениях Восточной Сибири // Известия вузов. Горный журнал. 2019. № 5. C. 21-29 (In Eng.). DOI: 10.21440/0536-1028-2019-5-21-29

For citation: Sosnovskaia E. L., Avdeev A. N. Control over the geotechnical processes at the goldfields of Eastern Siberia. Izvestiya vysshikh uchebnykh zavedenii. Gornyi zhurnal = News of the Higher Institutions. Mining Journal. 2019; 5: 21-29. DOI: 10.21440/0536-1028-2019-5-21-29 